\title{
FOLATE DETERMINATION IN CASHEW APPLE JUICE: METHOD DEVELOPMENT AND VALIDATION
}

\author{
S. O. Sancho', A. R. A. Silva ${ }^{1}$, M. C. Rabelo', R. W. Figueiredo', G. A. Maia ${ }^{1}$ and S. Rodrigues ${ }^{1}$ \\ 'Department of Food Technology - Federal University of Ceará, Brazil. \\ soraya_sancho@yahoo.com.br, anaraquelaraujosilva@yahoo.com.br, tianerabelo@yahoo.com.br, \\ figueira@ufc.br, gmaia@secrel.com.br, sueli@ufc.br
}

Artigo submetido em julho/2012 e aceito em agosto/2012

\section{RESUMO}

Embora a literatura apresente avanços nos métodos para a determinação de folatos, estas publicações geralmente abordam alimentos enriquecidos. Até o presente, a maior parte dos métodos publicados para a determinação de vitaminas solúveis do complexo $B$, por Cromatografia Líquida de Alta Eficiência (CLAE), utilizam soluções tampão e agentes tensoativos como fase móvel, fazendo da quantificação um processo laborioso e caro. Deste modo, no presente trabalho, um método simples baseado na Extração em Fase Sólida (EFS), seguido de separação por CLAE foi desenvolvido e validado para quantificar os níveis de folato naturalmente presentes no suco de caju. A separação foi obtida utilizando água e uma pequena quantidade de acetonitrila, em fluxo de gradiente, como solventes de eluição do sistema. O método desenvolvido apresentou os requisitos necessários para sua aplicação como um protocolo laboratorial para quantificar folatos em suco de caju: boa linearidade, precisão e exatidão. As amostras de suco de caju analisadas neste trabalho apresentaram teores de folato de 0,74 a $1,32 \mathrm{mg} /$ $L$, fazendo do suco de caju uma boa fonte de folato.

PALAVRAS-CHAVE: desenvolvimento de método, folato, extração em fase sólida, cromatografia líquida.

\section{ABSTRACT}

Although the open literature presents advances in methods for folates determination, these publications usually covers fortified foods. Up to date, most of the published HPLC methods for soluble B-vitamins determination use buffer solutions and surfactants as mobile phase, making the quantification procedure laborious and expensive. Thus, in the present work, a simple method based on Solid Phase Extraction (SPE), followed by separation by high performance liquid chromatography was developed and validated in order to quantify the levels of folate naturally present in the cashew apple juice. The separation was achieved using water and a small amount of acetonitrile in gradient flow as solvent elution system. The developed method presented the necessary requirements for its application as a laboratory protocol to quantify folates in cashew apple juice: good linearity, precision and accuracy. The cashew apple juice samples analyzed in this study presented folate contents ranging from 0.74 to $1.32 \mathrm{mg} / \mathrm{L}$, making cashew apple juice a good folate source.

KEY-WORDS: method development, folate, solid phase extraction, liquid chromatography. 


\section{FOLATE DETERMINATION IN CASHEW APPLE JUICE: METHOD DEVELOPMENT AND VALIDATION}

\section{INTRODUCTION}

Cashew apple (Anacardium occidentale L.) juice is the second most consumed juice in Brazil (Broizini et al., 2007; Lima et al., 2007). This juice is a rich source of vitamin C (Lima et al., 2007) and also presents functional properties related to cancer prevention due to its antioxidant content (Kubo et al., 1993). Moreover, scientific investigations have demonstrated that cashew kernels have beneficial effects on health, particularly on chronic diseases such as hypertension and obesity, coronary heart disease, and diabetes. The high content of unsaturated fatty acids of nut kernels is one of the most determinant factors against cardiovascular disease and obesity (Mexis and Kontominas, 2009; Yang, 2009; Yang et al., 2009). Although vitamin C is the most abundant micronutrient in cashew apple juice, other vitamins such as B-vitamins are also present (Cianci et al., 2005).

Folic acid (vitamin $B_{9}$ ) is a water soluble B-vitamin that belongs to the folates family (Gliszczynska-Swiglo, 2006). Man is unable to synthesize folic acid but processes aproximately 15 enzymes that carry out transformation of preformed folates in cellular metabolism. Folate is a generic description of compounds that have nutritional properties and chemical structure similar to folic acid (Gupta et al., 2011). Among 100 folate compounds, folic acid and 5methyltetrahydrofolic acid (5-MTHF), are the most commonly reported forms (Gregory, 1989). The presence of folic acid is almost non-existent in plant and animal foods whereas 5-MTHF, 5formyltetrahydrofolate, 10 -formyltetrahydrofolate and other reduced folates are more abundant (Ginting and Arcot, 2004).

Folic acid is a common form of folate used for food fortification to prevent the incidence of neural birth defects among others (Shrestha et al., 2012). Folates are antioxidant and anticarcinogenic activity (Phillips et al., 2005; Abramssom-Zettemberg et al., 2006; Opladen et al., 2006).

Although folate and folic acid are very similar in structure, folate is not stable as folic acid, being more easily damaged by cooking and processing of the food. Because of that, food fortification with synthetic folic acid is common. However, foods with high amounts of antioxidants can present a very stable folate content. Orange juice presents stable folate content due its high amount of ascorbid acid (Stinson et al., 2000).

Except for vitamin C, no published works on cashew apple juice B vitamins determination were found. Orange juice is the most studied juice around the world presenting several similarities to cashew apple juice such as: high vitamin $C$ and carotenoids contents. The folate in orange is found in the form of 5-methyltetrahydrofolic acid (Matella et al., 2005; Young et al., 2011). Folate in orange juice can account for up to $20 \%$ of the recommended dietary allowance per serving. The enzyme treatment may contribute to analytical variability, and several hours may be needed to completely hydrolyze folates in citrus products to their monoglutamate forms. Consequently, there is a need for faster and more reproducible methods for analysis of the various forms of folate in citrus juices (Matella et al., 2005).

According to Jastrebova et al. (2003) the data available on folate contents in food are contradictory due to the analytical procedure difficulties. Usually the folate content of food is 
quantified by time consuming microbiological assays, carried out as Lactobacillus casei-based turbidimetric assay or titrimetric methods (AOAC, 1995; Lim et al., 1998).

High performance liquid chromatography (HPLC) is a technique that is also used to determine folic acid and folates applied in multivitamin tablets, foods, beverages and pharmaceutical preparations (Zhang et al., 2009; Brouwer et al., 2010; Young et al., 2011; Deconinck et al., 2011) is regularly checked by the competent authorities. The United States Pharmacopoeia describes a HPLC method for the quantification of folic acid in tablets (U.S.P.C, 2010), but does not take into account that folic acid is often present in formulations containing other water soluble vitamins and nutritional supplements.

However, no simple, rapid and reliable high-performance liquid chromatography method is reported in the literature for cashew apple juice. Usually HPLC water-soluble vitamins determination is carried out using buffers and expensive surfactants as eluent (Breithaupt, 2001; Almagro et al., 2002). No published data was found for folate determination in non-fortified fruit juices, specially for cashew apple juice. The main challenge of folate determination in cashew apple juice is the high content of organic acids (including vitamin C) found in this juice which affects the sample clean up step. Thus, a simple method based on solid phase extraction (SPE), followed by liquid chromatographic separation with UV-detection was developed to determine folate in cashew apple juice using only water and acetonitrile as eluent. No previous method using such solvent systems for soluble vitamin determination is available.

\section{MATERIALS AND METHODS}

\subsection{Reagents and standards}

Acetonitrile HPLC grade from Tedia Company Inc. (Fairfield, $\mathrm{OH}$ - USA) and ultra pure water obtained by MilliQ System (Millipore, SP-Brazil) filtered in a $0.45 \mu \mathrm{m}$ cellulose acetate membrane (Millipore, SP-Brazil) were used as solvent for chromatography. Folate standard (5methyltetrahydrofolic acid disodium salt - Sigma-Aldrich), folate standard was purchased in lyophilized form and stored at $-20^{\circ} \mathrm{C}$ and folic acid standard was stored at $4{ }^{\circ} \mathrm{C}$.

\subsection{Samples}

Commercial cashew apple juice used in the present work was kindly provided by a local industry. Single strength juice with high pulp content was used. The samples were collected, centrifuged at $11.806 \mathrm{xg}(8.000 \mathrm{rpm})$ for 10 minutes and stored frozen $\left(-18^{\circ} \mathrm{C}\right)$ prior to analysis. The juice was initially characterized by $\mathrm{pH}$ determination using a potentiometer and total acidity, as citric acid equivalents, by titration with $\mathrm{NaOH}$.

The juice was obtained from in natura cashew peduncles purchased from the local market (Mercado São Sebastião Fortaleza-CE) during the harvest season. The cashew nut was removed and the juice was extracted using a hand mixer. The juice was stored frozen $\left(-20^{\circ} \mathrm{C}\right)$ prior to use without any additive addition. 


\subsection{Sample treatments for folate quantification (SPE)}

Prior to SPE extraction $10 \mathrm{~mL}$ of the sample were filtered in borosilicate membranes (FMS, CA-USA). The sample clean-up was performed in a three step procedure using two kinds of cartridges $\mathrm{C}_{18} 500 \mathrm{mg} / 6.0 \mathrm{~mL}$ (Supelco, PA-USA) and SAX $500 \mathrm{mg} / 6.0 \mathrm{~mL}$ (AccuBond II SAX, UK). The $C_{18}$ SPE cartridge was conditioned by sequential elution with $5 \mathrm{~mL}$ methanol and $10 \mathrm{~mL}$ of water. After the final washing step $2 \mathrm{~mL}$ of the sample was transferred to the cartridge. The eluted sample was then cleaned in two steps with the SAX cartridge. The cleanup procedure was as follows: the SPE Cartridge $(500 \mathrm{mg} / 6.0 \mathrm{~mL}$ ) was conditioned by sequential elution with $6 \mathrm{~mL}$ of $\mathrm{n}$-hexane, $6 \mathrm{~mL}$ of methanol and $10 \mathrm{~mL}$ of water not allowing the column to run dry. The sample eluted from the $\mathrm{C}_{18}$ cartridge was sequentially eluted with two SAX cartridges at about $1 \mathrm{drop} / \mathrm{s}$. Folate was eluted from the second SAX cartridge with $1 \mathrm{~mL}$ of $0.1 \mathrm{M}$ sodium acetate buffer $\mathrm{pH}$ 4.9 containing $10 \%(\mathrm{p} / \mathrm{v})$ of sodium chloride. The analysis was carried out just after the sample preparation. However, the stock solutions presented good stability when stored for 30 days at 4 ${ }^{\circ} \mathrm{C}$. Extractions were done in duplicate.

\subsection{Sample quantification}

The analyte was quantified using the external standard method. Calibration curves were built diluting stock solutions containing $30 \mathrm{mg} / \mathrm{L}$ of the standard diluted in MilliQ water. Calibration curves were obtained by linear regression using the software StarChrom WS 5.51 (Varian) and considering a minimum correlation coefficient of 0.995. A total of nine samples of commercial cashew apple juice and one sample of in natura cashew apple juice were analyzed.

The cleaned samples and standards were previously filtered in $0.45 \mu \mathrm{m}$ nylon membrane (FMS, CA-USA) and injected into the chromatographic system. Injections were done in triplicate and the analyte identity was confirmed by the retention time and by spiking the sample with the standard.

A Varian Pro Star HPLC system with two high-pressure pumps model Pro-Star 210, a column oven Timberline model 101, a double channel UV-detector Pro-Star model 345 with programmable wavelength variation and a Rheodyne injector loop of $20 \mu \mathrm{L}$ was used. The separations were achieved in an ACE-C18 column ( $250 \mathrm{~mm} \times 4 \mathrm{~mm})$.

\subsection{HPLC conditions}

The elution solvents used were: phase A (ultrapure water) and phase B (acetonitrile). The samples were eluted according to the gradient presented in Table 1 . The detection was done at $285 \mathrm{~nm}$. Flow rate was $1.00 \mathrm{~mL} / \mathrm{min}$ and run time 18 minutes. The run was performed at $35^{\circ} \mathrm{C}$. The sample injection volume was $20 \mu \mathrm{L}$. The analyte identification was achieved by comparing its retention time values with the standard. Quantification was done using external standard $(0.50-3.0 \mathrm{mg} / \mathrm{mL})$. The data was acquired and handled by StarChrom WS 5.51 software.

Table 1. HPLC conditions

\begin{tabular}{lll}
\hline Time $(\min )$ & Solvent A $(\%, v / v)$ & Solvent B $(\%, v / v)$ \\
\hline
\end{tabular}




\begin{tabular}{lll}
\hline $0: 00$ & 99 & 1 \\
$7: 00$ & 15 & 85 \\
$15: 00$ & 15 & 85 \\
$18: 00$ & 1 & 99 \\
\hline
\end{tabular}

Solvent A: Water. Solvent B: Acetonitrile.

\subsection{Evaluation of the use of folic acid as standard in HPLC assay}

Due to its chemical similarity with 5-methyltetrahydrofolate (Fig.1), folic Acid HPLC grade Fluka (Steinhein, Germany) was used as standard for HPLC analysis. In order to make sure that the folic acid could be employed instead folate (5-MTHF), the absorptivity at $285 \mathrm{~nm}$ of both compounds; their retention times and signals intensity in HPLC systems were evaluated.
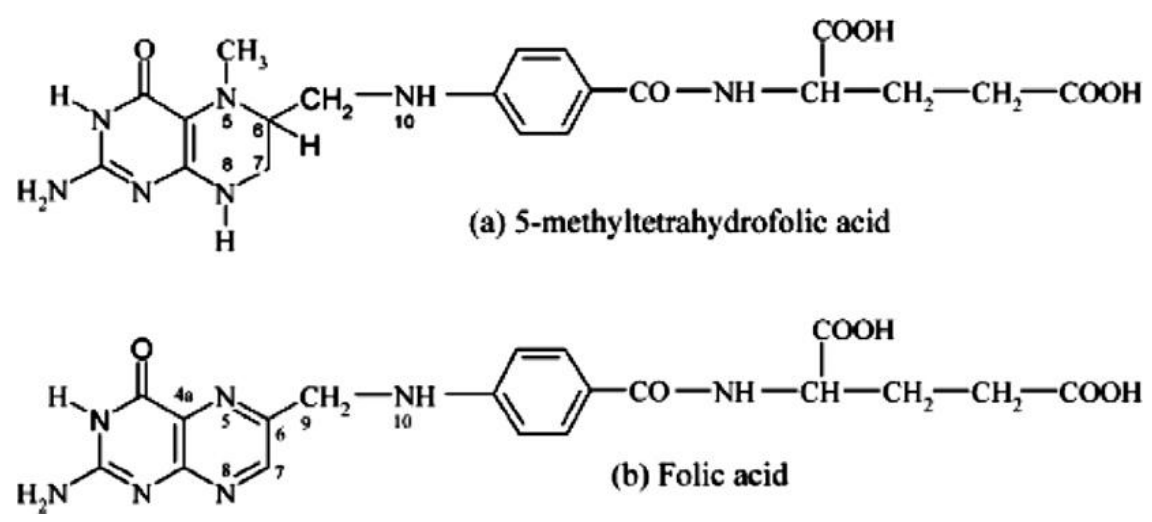

Figure 1 - Chemical structure of 5-methyltetrahydrofolic acid (a) and folic acid (b) (Arcot and Shrestha, 2005).

Absorptivity of folate and folic acid was determined by measuring the absorbency of both compounds diluted in acetonitrile: water (15:85 v/v) at $285 \mathrm{~nm}$. The Lambert Beer law was used to calculate the compounds absorptivity by linear regression. The assay was carried out in a UVVIS spectrophotometer (Spectrum -2000) using a $3 \mathrm{~mL}$ square quartz cell with $1 \mathrm{~cm}$ of pathway length. The results were compared by Tukey test considering a confidence interval of $95 \%$. Origin $7.5 \mathrm{v}\left(\right.$ OriginLab $^{\odot}$ ) software was used to process the data.

\section{RESULTS AND DISCUSSION}

The sample clean up is a very important step in complex matrices samples as fruit juices. In case of cashew apple juice the use of the standard clean up protocol using only one SAX cartridge (Breithaupt, 2001) did not work due to the high content of organic acid, including ascorbic acid (vitamin C), presented in the samples. The juice samples presented $\mathrm{pH}$ around $3.7 \pm$ 0.02 and acidity, as citric acid, raging from $6.60 \pm 0.20$ to $8.00 \pm 1.0 \mathrm{~g} / \mathrm{L}$. This high acidity content saturated the SAX cartridge and the folate was not retained when only one SAX cartridge was used. The SPE protocol reported in this work was found after several tests. The first cartridge 
$\left(C_{18}\right)$ removes the colored compounds allowing a better performance of the SAX cartridges. In the first SAX cartridge, high amounts of organic acids were retained allowing the proper sample clean up since folate amount is significantly lower than vitamin C (Sancho, 2006).

\subsection{Method Validation}

\subsubsection{Wavelength choice}

Standards injections at three different wavelengths $(214 \mathrm{~nm}, 254 \mathrm{~nm}$ and $285 \mathrm{~nm}$ ) were carried out in order to check the best response for folic acid in the cleaned sample. The wavelength of $285 \mathrm{~nm}$ was chosen after identification of the best wavelength response of folic acid as well as its intensity and evaluation of the peak shape.

Absportivity of the standards used in this work, folic acid and 5-methyltetrahydrofolic acid

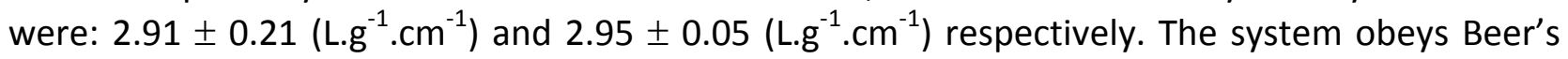
Law in the in the range of 0.4 to $1.0 \mathrm{~g} / \mathrm{L}$ at $285 \mathrm{~nm}$ in the organic phase $\mathrm{H}_{2} \mathrm{O}$ :acetonitrile $(85: 15 \mathrm{v} / \mathrm{v})$, with absorbance values ranging from 0.250 to 2.100 . The mean results were submitted to Turkey test at $95 \%$ of confidence interval and presented no significant differences.

The use of folic acid instead of 5-methyltetrahydrofolic acid, disodium salt, was also based on the fact that both standards presented the same retention time and signal response in the HPLC system. Calibration curves did not showed significant differences (see item 3.1.3).

No significant differences were fond for each tested sample concentration. As folic acid is cheaper and more stable than 5-methyltetrahydrofolic acid, this chemical was chosen as standard for HPLC analysis.

\subsubsection{Separating condition}

The best separating condition was obtained after several tests where mobile phase, elution gradient and column temperature were evaluated. The best HPLC condition found was: column temperature of $35^{\circ} \mathrm{C}$, total flux of $1.00 \mathrm{~mL} / \mathrm{min}$, two different mobile phases (acetonitrile and water) and elution gradient as presented in Table 1 . A very well shaped and clearly separated single peak of folate as shown in Figure 2 was obtained. 



Figure 2 - Chromatograms. Cashew apple juice without SPE extraction (A); Cashew apple juice after SPE extraction (B); Both previous chromatograms (C).

\subsubsection{Calibration curve}

Quantifications were done by the external standard method and the calibration curve was built by linear regression with the data obtained from the peak height after triplicate injection of water solutions containing $0.50 ; 0.75 ; 1.00 ; 2.00$ and $3.00 \mathrm{mg} / \mathrm{L}$ of folic acid. The parameters of the calibration curve as well as the correlation coefficient $(r)$ of the calibration plots for folic acid is presented in Table 2. Calibration plot is expressed as linear regression equations $(y=a+b x)$, where $y$ is the peak height and $x$ is the concentration of the analyte $(\mathrm{mg} / \mathrm{L})$. The same procedure was also carried out for 5-methyltetrahydrofolic acid (5-MTHF) as standard and no significant differences were found (Table 2). Solutions of 5-methyltetrahydrofolic acid were prepared freshly and immediately used.

Table 2. Retention time (RT), parameters and correlation coefficients ( $r$ ) of the calibration plot

\begin{tabular}{ccccc}
\hline Compound & $\mathbf{R T}(\min )$ & $a$ & $b$ & $R^{2}$ \\
\hline Folic acid & 10.20 & 1.46 & 0.47 & 0.9996 \\
5-MTHF & 10.00 & 1.43 & 0.48 & 0.9978 \\
\hline
\end{tabular}




\subsubsection{Selectivity}

At the optimized separating condition chromatograms with optimized resolution peaks were obtained (Fig. 2). The method presented good selectivity since the presence of other compounds did not cause any interference in the analysis.

\subsubsection{Detection and quantification limits}

The linear range for folic acid was $0.50-3.00 \mathrm{mg} / \mathrm{L}$. Estimated detection limit was obtained after successive dilutions (at 1:1 proportions) of a $3.00 \mathrm{mg} / \mathrm{L}$ standard solution until the signal-to-ratio noise in peak heights was 3:1 in $\mathrm{mV}$. Quantification limits were obtained in the same way until the signal ratio-to-noise was 5:1 (Aquino et al., 2006). Folic acid presented a detection limit of $0.25 \mathrm{mg} / \mathrm{L}$ and quantification limit of $0.50 \mathrm{mg} / \mathrm{L}$.

\subsubsection{Precision}

The precision study was comprised of repeatability of 10 consecutive injections of a 2.5 $\mathrm{mg} / \mathrm{L}$ standard solution of folic acid. The results were submitted to a statistical evaluation and the method precision was established as presented in Table 3 . The precision of the method is characterized by the relative standard deviation (RSD). The developed method presented $0.79 \%$ of RSD, which is satisfactory for the considered analysis (Swartz and Krull, 1997).

Table 3. Repeatability of the quantitative analysis

\begin{tabular}{cccc}
\hline Compound & $\operatorname{Mean}^{n}(\mathrm{mg} / \mathrm{L})$ & SD & RSD (\%) \\
\hline Folic acid & 2.53 & 0.02 & 0.79 \\
\hline$n$ m average of 10 and
\end{tabular}

$n=$ average of 10 analyses, SD = standard deviation, RSD relative standard deviation.

\subsubsection{Accuracy}

Analytical accuracy was evaluated by spiking a previously analyzed sample with the standard. The recovery level was determined according to equation 1 . The recovery of folic acid was $98.40 \%$, which can be considered satisfactory for the considered analysis (Swartz and Krull, 1997).

$\operatorname{Recov}$ ery $(\%)=\left(\frac{\text { measured concentration }}{\text { exp ected concentration }}\right) \times 100$

\subsection{Folate determination in processed cashew apple juice from Ceará State (Brazil)}

Table 4 presents the folate content of the analyzed samples. Cashew apple juice presented folate contents ranging from 0.74 to $1.32 \mathrm{mg} / \mathrm{L}$. Thus $250 \mathrm{~mL}$ (a bottle) of the analyzed cashew apple juice samples contains 185 to $330 \mu$ g of folate corresponding to 46.3 to $82.5 \%$ of the recommended daily intake of $400 \mu \mathrm{g}$ for pregnant women, according to the US Center for 
Disease Control and Prevention (CDC, 1996) and 63.6 to $126.5 \%$ of the recommended daily intake of $291 \mu \mathrm{g}$ for adults according to Bree et al. (1997). Although the processed juice passed through thermal treatments (pasteurization for 1 minute at $90^{\circ} \mathrm{C}$ ), as previously reported for orange juice, the high vitamin $\mathrm{C}$ content of the juice was able to preserve the vitamin retaining good amounts.

Table 4. Folate content in cashew apple juice samples

\begin{tabular}{ccc}
\hline Sample & Mean $^{n}(\mathrm{mg} / \mathrm{L})$ & SD \\
\hline 2 & 0.92 & 0.05 \\
3 & 0.94 & 0.04 \\
4 & 0.94 & 0.02 \\
5 & 1.27 & 0.03 \\
6 & 1.32 & 0.06 \\
7 & 1.27 & 0.06 \\
8 & 0.74 & 0.05 \\
9 & 1.14 & 0.08 \\
\hline$n=$ average of 3 analyses, SD $=$ standard deviation &
\end{tabular}

Neuhouser et al. (1998) reported that for the ingestion of $400 \mu \mathrm{g}$ of folate from orange it is necessy a portion of $950 \mathrm{~mL}$. According to Stinson et al. (2000) a portion of $240 \mathrm{~mL}$ of orange juice contains about 60-70 $\mu \mathrm{g}$ of natural folate. The reported natural folate found in citrus juice ranged from 300 to $700 \mu \mathrm{g} / \mathrm{L}$ (Dong and Oace, 1973; Gregory et al., 1984; White, 1990; White et al., 1991). Comparing the previous results published for orange and citrus juice, cashew apple juice presented higher folate content than other assayed citrus juices, being a good source of natural folate.

\section{CONCLUSIONS}

This study presented a method developed for folate determination in cashew apple juice. The sample clean up was a key factor in the analysis. A three-step sample cleaning process was necessary to avoid the interference of organic acids present in high amounts in cashew apple juice. High amounts of folate were found in cashew apple juice and a consumption of $250 \mathrm{~mL}$ of this juice could supply at least $50 \%$ of the recommended daily intake of folates from food sources. 
The developed method presented the necessary requirements for its application as a laboratory protocol to quantify folates in cashew apple juice: good linearity, precision and accuracy. Besides, the method is very simple and inexpensive solvents were used (the mobile phase is basically water with small amounts of acetonitrile in gradient flow). In this work it was showed that a simple solvent system could be employed. The method may also be extended to other beverages, if a convenient clean-up procedure is used for each case.

Cashew apple juice folate content was higher than the reported for orther citrus juices, including orange juice. The folate content found in natural and industrialized cashew apple juice assayed by HPLC method (at least $0.90 \mathrm{mg} / \mathrm{L}$ ) was more than two times the reported for orange juice (about $0.42 \mathrm{mg} / \mathrm{L}$ ) by Neuhouser et al. (1998), making cashew apple juice a good folate source.

\section{REFERENCES}

1. ABRAMSOON-ZATTERBERG, L., DURLING, L.J., YANG-WALLENTIN, F., RYTTER, E., VESSBY, B. The impact of folate status and folic acid supplementation on the micronucleus frequency in human erythrocytes. Mutation Research, v. 603, n. 1, p. 33-40, 2006.

2. AKINWALE, T. O. Cashew apple juice: its use in fortifying the nutritional quality of some tropical fruits. European Food Research and Technology, v. 211, n. 3, p. 205-207, 2000.

3. ALMAGRO, I., SAN ANDRES, M. P., VERA, S. Determination of water-soluble vitamins in pharmaceutical preparations by reversed phase high-performance liquid chromatography with mobile phase containing sodium dodecylsulfate and n-propanol. Chromatographia, v. 55, n. 3-4, p. 185-188, 2002.

4. AOAC - Association of Official Analytical Chemistry. Methods for microbiological analysis of seleted nutrients. Washington: AOAC, 1996.

5. AQUINO, F. W., RODRIGUES, S., NASCIMENTO, R. F., CASIMIRO, A. R. S. Simultaneous determination of aging markers in sugar cane spirits. Food Chemistry, v. 98, n. 3, p. 569-574, 2006.

6. ARCOT, J., SHRESTHA, A. K. Methods of folate analysis - A review. Trends in Food Science and Technology, v. 16, p. 253-266, 2005.

7. ASSUNÇÃO, R. B., MERCADANTE, A. Z. Carotenoids and ascorbic acid composition from commercial products of cashew apple (Anacardium occidentale L.). Journal of Food Composition and Analysis, v. 16, n. 6, p. 647-657, 2003.

8. BRADFORD, M. M. A rapid and sensitive method for the quantization of microgram quantities of protein utilizing principle of protein-dye binding. Analytical Chemistry, v. 72, p. 248-254, 1976.

9. BREE, A., VAN DUSSELDORP, M., BROUWER, I. A., VAN HET HOF, K. H., STEERGERSTHEUNISSEN, R. P. M. Folate intake in Europe: recommended, actual and desired intake. European Journal of Clinical Nutrition, v. 51, n. 10, p. 643-660, 1997.

10. BREITHAUPT, D. E. Determination of folic acid by ion-pair RP-HPLC in vitamin-fortified fruit juices after solid-phase extraction. Food Chemistry, v. 74, n. 4, p. 521-525, 2001. 
11. BROIZINI, P. R. B., ANDRADE-WARTHA, E. R. S., SILVA, A. M. O., NOVOA, A.J.V., TORRES, R.P., AZEREDO, H.M.C., ALVES, R.E., MANCINI-FILHO, J. Avaliação da atividade antioxidante dos compostos fenólicos naturalmente presentes em subprodutos do pseudofruto de caju (Anacardium occidentale L.). Ciência e Tecnologia de Alimentos, v. 27, n. 4, p. 902-908, 2007.

12. BROUWER, V., STOROZHENKO, S., STOVE, C.P., VAN DAELE, J., VAN DER STRAETEN, D., LAMBERT, W.E. Ultra-performance liquid chromatography-tandem mass spectrometry (UPLC-MS/MS) for the sensitive determination of folates in rice. Journal Chromatography $B$, v. 878, p. $509-513,2010$.

13. CDC - US Center for Disease Control and Prevention. Knowledge about folic acid and use of multivitamins containing folic acid among reproductive-aged women. Morbidity and Mortality Weekly Report, v. 45, n. 37, p. 793-795, 1996.

14. CIANCI, F. C., SILVA, L. M. F., CABRAL, L. M., MATTA, V. M. Clarificação e concentração de suco de caju por processos com membranas. Ciência e Tecnologia de Alimentos, v. 25, n. 3, p. 579-583, 2005.

15. DECONINCK, E., CREVITS, S., BATEN, P., COURSELLE, P., BEER, J. A validated ultra high pressure liquid chromatographic method for qualification and quantification of folic acid in pharmaceutical preparations. Journal of Pharmaceutical and Biomedical Analysis, v. 54, p. 995-1000, 2011.

16. DOHERTY, R. F., BEECHER, G. R. A method for the analysis of natural and synthetic folate in foods. Journal of Agricultural and Food Chemistry, v. 51, n. 2, p. 354-361, 2003.

17. DONG, F. M., OACE, S. M. Folate distribution in fruit juices. Journal of American Dietary Association, v. 62, n. 2, p. 162-166, 1973.

18. GINTING, E., ARCOT, J. High-performance liquid chromatographic determination of naturally occurring folates during tempeh preparation. Journal of Agricultural and Food Chemistry, v. 52, p. 7752-7758, 2004.

19. GLISZCZYNSKA-SWIGLO, A. Folates as antioxidants. Food Chemistry, v. 101, n. 4, p. 14801483, 2007.

20. GREGORY, J. F. Chemical and nutritional aspects of folate research: Analytical procedures, method of analysis, stability, and bioavailability of dietary folates. Advances in Food Nutrition Research, v. 33, p. 1-101, 1989.

21. GREGORY, J. F., SARTAIN, D. B., DAY, B. P. F. Fluorometric determination of folacin in biological materials using high performance liquid chromatography. Journal of Nutritrion, $\mathrm{v}$. 114, n. 2, p. 341- 353, 1984.

22. GUPTA, V.K., JAIN, R., AGARWAL, S., MISHRA, R., DWIVEDI, A. Electrochemical determination of antihypertensive drug irbesartan in pharmaceuticals. Analytical Biochemistry, v. 410, p. 266-271, 2011.

23. HOLLER, U., BRODHAG, C., KNOBEL, A., HOFMANN, P., SPITZER, V. Automated determination of selected water-soluble vitamins in tablets using a bench-top robotic system coupled to reversed-phase (RP-18) HPLC with UV detection. Journal of Pharmaceutical and Biomedical Analysis, v. 31, n. 1, p. 151-158, 2003. 
24. HYUNG-SOO, K., DUCK-KYU, J., DONG-KYUN, W., KANG-LYUNG, W. Simultaneous determination of the water soluble vitamins in multi-nutrient tablets by reversed-phase highperformance liquid chromatography. Journal of Food Science and Nutrition, v. 7, n. 1, p. 1217, 2002.

25. JASTREBOVA, J., WITTHOFT, C., GRAHN, A., SVENSSON, U., JAGERSTAD, M. HPLC determination of folates in raw and processed beetroots. Food Chemistry, v. 80, n. 4, p. 579588, 2003.

26. KALIMUTHU, P., JOHN S. A. Selective electrochemical sensor for folic acid at physiological pH using ultrathin electropolymerized film of functionalized thiadiazole modified glassy carbon electrode. Biosensors and Bioelectronics, v. 24, n. 12, p. 3575-3580, 2009.

27. KUBO, I., OCHI, M., VIEIRA, P. C., KOMATSU, S. Antitumor agents from the cashew (Anacardium occidentale) apple juice. Journal of Agricultural and Food Chemistry, v. 41, n. 6, p. $1012-1015,1993$.

28. LAURENCE, K. M., JAMES, N. MileR, M. H., TENNAT, G. B., CAMPBELL, H. Double-blind randomised controlled trial of folate treatment before conception to prevent recurrence of neural-tube defects. British Medical Journal, v. 282, n. 6275, p. 1509-1511, 1981.

29. LIM, H. S., MACKEY, A. D., TAMURA, T., WONG, S. C., PICCIANO, M. F. Measurable human milk folate is increasing by treatment with $\alpha$-amilase and protease in addition to folate conjugase. Food Chemistry, v. 63, n. 3, p. 401-407, 1998.

30. LIMA, E. S., SILVA, E. G., MOITA-NETO, J. M., MOITA, G. C. Redução de vitamina C em suco de caju (Anacardium occidentale L.) industrializado e cajuína. Química Nova, v. 30, n. 5, p. 11431146, 2007.

31. MATELLA, N. J., BRADDOCK, R. J., GREGORY J. F., GOODRICH, R. M. Capillary electrophoresis and high-performance liquid chromatography determination of polyglutamyl 5methyltetrahydrofolate forms in citrus products. Journal of Agricultural and Food Chemistry, v. 53, n. 6, p.2268-2274, 2005.

32. MEXIS, S. F., KONTOMINAS, M. G. Effect of g-irradiation on the physicochemical and sensory properties of cashew nuts (Anacardium occidentale L.). Lebensmittel-Wissenschaft und Technologie, v. 42, p. 1501-1507, 2009.

33. MRC VITAMIN STUDY RESEARCH GROUP. Prevention of neural tube defects: results of the medical research council vitamin study. Lancet, v. 338, p. 131-137, 1991.

34. MUNYAKA, A. W., OEY, I., VERLINDE, P., LOEY, A. V., HENDRICKX, M. Acidification, crushing and thermal treatments can influence the profile and stability of folate poly- $\gamma$-glutamates in broccoli (Brassica oleracea L. var. italica). Food Chemistry, v. 117, n. 3, p. 568-575, 2009.

35. NEUHOUSER, M. L., BERESFORD, S. A. A., HICKOK, D. E., MONSEN, E. R. Absorption of dietary supplemental folate in women with prior pregnancies with neural tube defects and controls. Journal of American College of Nutrition, v. 17, n. 6, p. 625-630, 1998.

36. OFFICIAL METHODS OF ANALYSIS OF THE ASSOCIATION OF ANALYTICAL CHEMISTS. Folic acid (pteroylglutamic acid) in vitamin preparations $\left(16^{\text {th }}\right.$ ed., 1995), sections 45.2 .03 and 50.1.21; Recovery studies: p. XXII, item 25 (14 th ed., 1984). Richmond (VA): The William Byrd Press. 
37. Opladen, T., RAMAekers, V. T. H., HeIMAN, G., BALU, N. Analysis of 5methyltetrahydrofolate in serum of healthy children. Molecular Genetics and Metabolism, v. 87, p. 61-65, 2006.

38. OSSEYI, E. S., WEHLING, R. L., ALBRECHT, J. A. Liquid chromatographic method for determining added folic acid in fortified cereal products. Journal of Chromatography $A, v$. 826, n. 2, p. 235-240, 1998.

39. PAWLOSKY, R. J., FLANAGAN, V. P., DOHERTY, R. F. A mass spectrometric validated highperformance liquid chromatography procedure for the determination of folates in foods. Journal of Agricultural and Food Chemistry, v. 51, n. 1, p. 3726-3730, 2003.

40. PAWLOSKY, R. J., HERTRAMPF, E., FlanAGA, V. P., THOMAS, P. M. Mass spectral determinations of the folic acid content of fortified breads from Chile. Journal of Food Composition and Analysis, v. 16, n. 3, p. 281-286, 2003a.

41. PHILLIPS, K. M., WUNDERLICH, K. M., HOLDEN, J. M., EXLER, J., GEBHARDT, S. E., HAYTOWITZ, D. B., BEECHER, G. E., DORERTY, R. F. Stability of 5-methyltetrahydrofolate in frozen fresh fruits and vegetables. Food Chemistry, v. 92, p. 587-595, 2005.

42. RADER, J. L., WEAVER, C. M., ANGYAL, G. Use of a microbiological assay with tri-enzyme extraction for measurement of pre-fortification levels of folates in enriched cereal-grain products. Food Chemistry, v. 62, n. 4, p. 451-465, 1998.

43. ROBERTZ, R. L., KENEASTER, K. K. Effect of processing conditions on the expanded volume, color, and soluble starch of parboiled rice. Cereal Chemistry, v. 31, p. 121-129, 1954.

44. SANCHO, S. O. Efeito do processamento sobre características de qualidade do suco de caju. Fortaleza, 2006, 124p. Dissertação (Mestre em Tecnologia de Alimentos), Departamento de Tecnologia de Alimentos, Universidade Federal do Ceará (UFC).

45. SHEPPARD, S., NEVIN, N. C., SELLER, M. J., WILD, J., SMITHELLS, R. W., READ, A. P., HARRIS, R., FIELDING, D. W., SCHORAH, C. J. Neural tube defect recurrence after "partial" vitamin supplementation. Journal of Medical Genetics, v. 26, n. 5, p. 326-329, 1989.

46. SHRESTHA, A.K.K., ARCOT, J., YULIANI, S. Susceptibility of 5-methyltetrahydrofolic acid to heat and microencapsulation to enhance its stability during extrusion processing. Food Chemistry, v. 130, p. 291-298, 2012.

47. STINSON, W. S., WIDMER, W. W., MOORE, E. L. Health benefits of folic acid in orange juice. Annals of the $23^{\text {rd }}$ IFU Symposium, Habana- Cuba p. 328-339, 2000.

48. SWARTZ, M. E., KRULL, I. S. Analytical method development and validation, Marcel Dekker Inc.: New York, 1997.

49. U.S.P.C. United States Pharmacopoeia 35, United States Pharmacopeial Convention, Inc.,

50. WHITE JR., R. D. Determination of 5-methyltetrahydrofolate in citrus juice by reversed-phase high performance liquid chromatography with electrochemical detection. Journal of Agricultural Food Chemistry, v. 38, n. 7, p. 1515-1518, 1990.

51. WHITE JR., R. D., LEE, H. S., KRUGER, R. E. Reversed-phase HPLC/EC determination of folate in citrus juice by direct injection with column switching. Journal of Agricultural Food Chemistry, v. 39 , n. 4 , p. $714-717,1991$. 
52. WIGERTZ, K., JAEGERSTAD, M. Comparison of a HPLC and radioprotein-binding assay for the determination of folates in milk and blood samples. Food Chemistry, v. 54, n. 4, p. 429-436, 1995.

53. WILSON, S., HORNE, D. W. Use of glycerol-protected Lactobacillus casei for microbiological assay of folic acid. Clinical Chemistry, v. 28, n. 5, p. 1198-2000, 1982.

54. YANG, J. Brazil nuts and associated health benefits: a review. Lebensmittel- Wissenschaft und Technologie, v. 42, p. 1573-1580, 2009.

55. YANG, J., LIU, R. H., HALIM, L. Antioxidant and antiproliferative activities of common edible nuts. Lebensmittel-Wissenschaft und Technologie, v. 42, p. 1-8, 2009.

56. YOUNG, J. E., MATYSKA, M.T., PESEK, J.J. Liquid chromatography/mass spectrometry compatible approaches for the quantitation of folic acid in fortified juices and cereals using aqueous normal phase conditions. Journal of Chromatography A, v. 1218, p. 2121-2126, 2011.

57. ZHANG, H., CHEN, S., LIAO, W., REN, Y. Fast simultaneous determination of multiple watersoluble vitamins and vitamin-like compounds in infant formula by UPLC-MS/MS. Journal Food Agriculture Environment, v. 7, p. 88-93, 2009.

\section{ACKNOWLEDGMENTS}

The authors thank FUNCAP (Ceará State Foundation for Scientific and Technological Development Support) for the financial support and to CNPq for research scholarship. 